Citizens of a Christian Nation 


\section{POLITICS AND CULTURE}

\section{IN MODERN AMERICA}

\section{SERIES EDITORS}

Glenda Gilmore, Michael Kazin, Thomas J. Sugrue

Volumes in the series narrate and analyze political and social change in the broadest dimensions from 1865 to the present, including ideas about the ways people have sought and wielded power in the public sphere and the language and institutions of politics at all levels—local, national, and transnational. The series is motivated by a desire to reverse the fragmentation of modern U.S. history and to encourage synthetic perspectives on social movements and the state, on gender, race, and labor, and on intellectual history and popular culture. 


\section{Citizens of a Christian Nation}

Evangelical Missions and the Problem of Race in the Nineteenth Century

\section{Derek Chang}

\section{$\overline{\text { PENN }}$}

UNIVERSITY OF PENNSYLVANIA PRESS

PHILADELPHIA 
Copyright $(20$ 2o University of Pennsylvania Press

All rights reserved. Except for brief quotations used for purposes of review or scholarly citation, none of this book may be reproduced in any form by any means without written permission from the publisher.

Published by

University of Pennsylvania Press

Philadelphia, Pennsylvania I9104-4II2

Printed in the United States of America on acid-free paper

IO $\quad \begin{array}{lllllllll}9 & 8 & 7 & 6 & 5 & 4 & 3 & 2 & \text { I }\end{array}$

Library of Congress Cataloging-in-Publication Data

Chang, Derek.

Citizens of a Christian nation : Evangelical missions and the problem of race in the nineteenth century / Derek Chang.

p. cm. (Politics and culture in modern America)

Includes bibliographical references and index.

ISBN 978-0-8122-4218-8 (alk. paper)

1. American Baptist Home Mission Society—History—19th century. 2. Home missionsUnited States—History-19th century. 3. Baptists-Missions—United States-History19th century. 4. Evangelistic work-United States-History-19th century. 5. African Americans-Missions-History-19th century. 6. Chinese Americans-Missions-History - 19th century. 7. Whites—United States-Attitudes—History-19th century. 8. Missionaries-United States—Attitudes-History-19th century. 9. Racism-Religious aspects—Baptists—History-19th century. 10. United States—Race relations—Religious aspects—History—19th century. I. Title.

BV2766.B5C47 2010

$266.6131-\mathrm{dc} 22$ 
For my family

With special love and gratitude for Lauren, Max, and Isabel 
This page intentionally left blank 